\title{
DETECTION OF GENES RESISTANT TO BACTERIAL LEAF BLIGHT IN RICE CULTIVARS FROM SITUBONDO AND JEMBER, INDONESIA
}

\author{
Rasmiyana $^{1,2}$, Hardian Susilo Addy ${ }^{1,2,3,4}$, \& Erlia Narulita ${ }^{1,2}$ \\ ${ }^{1}$ Postgraduate Program, Program Study of Magister Biotechnology, University of Jember, Indonesia \\ ${ }^{2}$ Division of Biology Molecule and Biotechnology, Center for Development of Advanced Sciences and Technology, \\ University of Jember, Indonesia \\ ${ }^{3}$ Program Study of Plant Protection, Faculty of Agriculture, University of Jember, Indonesia \\ ${ }^{4}$ Center of Excellence on Crop Industrial Biotechnology, University of Jember, Indonesia \\ Jl. Kalimantan 37 Kampus Tegalboto, Jember, Jawa Timur 68121 \\ E-mail: hsaddy.faperta@unej.ac.id
}

\begin{abstract}
Detection of genes resistant to bacterial leaf blight in rice cultivars from Situbondo and Jember, Indonesia. Xanthomonas oryzae pv. oryzae (Xoo), causing bacterial leaf blight, is a destructive pathogen that significantly affects rice production. The use of resistant varieties is the most effective and economical strategy to reduce the impact of the disease. This study aimed to analyze the genetic basis of resistance to Xoo in rice. The incidence and severity of bacterial leaf blight were assessed in the field through a diagonal random sampling method. PCR was used to detect resistant genes in rice with eight $X a$-specific primers. The presence of $X a$ genes and environmental conditions were statistically analyzed to determine whether the disease incidence and disease severity were related to average temperature and rain intensity. The means for disease incidence and severity at the generative stage were higher than those at the vegetative stage. The 12 rice cultivars were categorized into four groups based on the presence of Xa gene sequences; most cultivars had Xa10 and Xa13, and one cultivar had five Xa genes. Disease incidence and severity were weakly correlated to the presence of resistance genes, as well as to environmental factors. Most rice cultivars from the Regencies of Jember and Situbondo carry Xa10 and Xa13 resistance genes.
\end{abstract}

Key words: bacterial leaf blight, $X a$ genes, $X a$ specific primers, Xanthomonas oryzae

\section{INTRODUCTION}

Rice (Oryza sativa L.) is one of the most important agricultural crops in the world. In Indonesia, rice is a main food crop, which has seen a continuous increase in production. However, plant pathogens, such as bacterial leaf blight, blast, tungro, and leafhopper (Almeida et al., 2016), have a negative impact on rice production in Indonesia. One destructive disease that significantly affects rice production is bacterial leaf blight (BLB), caused by Xanthomonas oryzae pv. oryzae. This pathogen can infect vegetative and generative phases of both resistant and susceptible cultivars of rice. However, infection by pathogen of BLB during vegetative stages may have a potentially more severe effect (Naqvi, 2019). The pathogen can cause yield loss, reaching $70-80 \%$, depending on the resistance level of the rice cultivar, the growth stage, and environmental factors (Wahyudi et al., 2011).

The control of BLB through the use of chemical pesticides, biological agents, plant extracts, and chitosan is still far from successful (Nisha et al., 2012). In addition, chemical pesticides continue to contaminate the environment, including the soil, water, turf, and other vegetation (Aktar et al., 2009). It is imperative that alternative control strategies, including the use of resistant varieties, that are effective, efficient, and economical are considered. Some varieties show different levels of resistance against different pathotypes of BLB (Susanto \& Sudir, 2012). The differences in resistance to the pathotypes are related to the presence and expression of resistance genes in rice plants (NiñoLiu et al., 2006). About $42 \mathrm{Xa}$ genes have been identified from rice cultivars, and are responsible for playing an essential role in the resistance against BLB (Arunakumari et al., 2016).

In Indonesia, the development of resistant cultivars has significantly increased through conventional and molecular breeding. Selection of germplasm carrying resistant genes is the crucial step for preparing parental resources. The presence of resistance genes in rice can be determined by using polymerase chain reaction (PCR)-based detection. Homozygous and heterozygous pairings of different combinations of the BLB resistance 
genes Xa1, Xa2, Xa3/Xa26, Xa4, Xa5, Xa7, Xa10, $x a 13$, and $X a 21$ have been used to develop new resistant rice cultivars (Perumalsamy et al., 2010; Singh et al., 2015). Recently, rice cultivars carrying 2-4 of the $42 \mathrm{Xa}$ genes have been reported (Arunakumari et al., 2016). Therefore, it is important to screen the genetic potential of local varieties of rice to identify superior candidates to provide sufficient data for producing resistant cultivars through molecular breeding. This study screened eight BLB resistance genes (Xal, Xa3, $X a 4, X a 5, X a 7, X a 10, X a 13$, and Xa21) in several rice varieties cultivated in Situbondo and Jember Regencies of Indonesia. In addition, a correlation analysis was performed to understand which factors influenced the highest resistance in rice against $X$. oryzae.

\section{MATERIALS AND METHODS}

Research Site. Twelve rice varieties, six each from different geographical locations in each of Jember and Situbondo Regencies of Indonesia (Figure 1), were collected in March 2018. The rice varietal name, developmental stage of the plant, and field location were recorded for each rice variety (Table 1). All samples were collected, placed in plastic bags and stored at $-20{ }^{\circ} \mathrm{C}$ until further use.

Assessment of Disease Incidence and Severity. Disease incidence and severity of BLB were assessed in the field through a diagonal random sampling method with 15-20 clumps per location. Disease incidence was calculated by the equation:

$$
\mathrm{DI}=\frac{\mathrm{n}}{\mathrm{N}} \times 100 \%
$$

$\mathrm{DI}=$ disease incidence,

$\mathrm{n}=$ number of symptomatic plants,

$\mathrm{N}=$ the total number of plants observed.

In addition, disease severity was calculated at the time of observation using the equation:

$$
\mathrm{DS}=\frac{\sum \mathrm{ni} \times \mathrm{vi}}{\mathrm{V} \times \mathrm{Z}} \times 100 \%
$$

$\mathrm{DS}=$ disease severity $(\%)$,

$\mathrm{ni}=$ number of clumps with disease scale value $\mathrm{i}$,

$\mathrm{vi}=$ value of disease scale $i$,

$\mathrm{V}=$ highest scale value,

$\mathrm{Z}=$ number of clumps observed.

The disease scale was scored by Mew \& Misra (1994): $0=$ no symptoms; $1=1-5 \%$ blight; $3=5-12 \%$ blight; $5=12-25 \%$ blight; $7=25-50 \%$ blight $9=50$ $100 \%$ blight.

In addition, the resistance of rice to BLB was categorized by the incidence of the disease as follows: resistant $(0-35 \%$ incidence); moderately resistant (36$70 \%$ incidence); and susceptible ( $>70 \%$ incidence) (Ilao \& Lastimosa, 1985). The category of resistance was based on severity, in accordance with the standard evaluation system, as follows: resistant (1-5\%); moderately resistant $(>5-12 \%)$; moderately susceptible $(>12-25 \%)$; susceptible $(>25-50 \%)$; and very susceptible (>50\%) (Mew \& Misra, 1994).

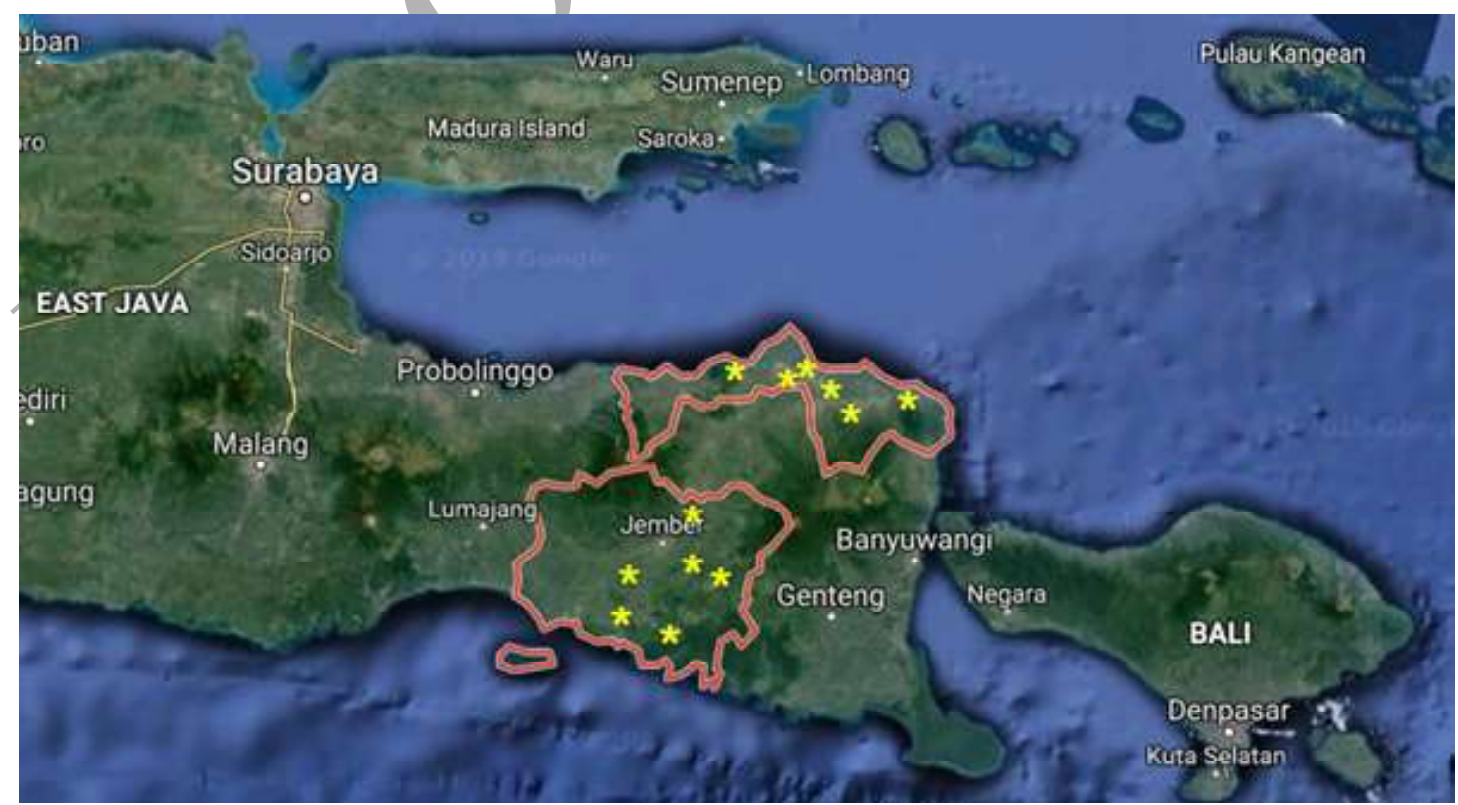

Figure 1. Locations of sample collection in two Regencies, Jember and Situbondo, of East Java, Indonesia. Asterisks $(*)$ represent sampling areas. 
Isolation of Plant DNA. Plant DNA was isolated from $0.5 \mathrm{~g}$ of rice leaves by grinding in liquid nitrogen, and dissolving in $500 \mu \mathrm{l}$ extraction buffer (containing $0.8 \mathrm{M}$ guanidine thiocyanate, $10 \mathrm{mM}$ EDTA, 5\% Tween 20, $0.5 \%$ Triton X-100, $50 \mathrm{mM}$ HEPES-acid), $25 \mu 1$ of $20 \%$ sodium dodecyl sulfate, and $1.25 \mu 1$ of â-mercaptoethanol. The sample was extracted by following the standard cetyl trimethylammonium bromide (CTAB) protocol, and purified by following the phenol chloroform isoamyl-alcohol (PCI) protocol (Sambrook $\&$ Russell, 2001). The extracted DNA was precipitated in ethanol and washed with $70 \%$ ethanol before dissolving in $30 \mu \mathrm{L}$ of TE buffer $(10 \mathrm{mM}$ Tris-HCL $\mathrm{pH}$ 8.0, $1 \mathrm{mM}$ EDTA $\mathrm{pH} 8.0$ ), to which $1 \mu \mathrm{L}$ of RNase A (20-40 mg/mL; Sigma, USA) was added, and kept at $-20{ }^{\circ} \mathrm{C}$ until use. The DNA quantity was measured using NanoVue ${ }^{\mathrm{TM}}$ Plus Spectrophotometer (GE Healthcare, UK).

Table 1. Sample codes, area of sampling, rice variety, growth stage, average temperature, and annual rainfall intensity

\begin{tabular}{llllcc}
\hline Codes & \multicolumn{1}{c}{ Area } & \multicolumn{1}{c}{ Varieties } & $\begin{array}{c}\text { Plant } \\
\text { growth } \\
\text { stage }\end{array}$ & $\begin{array}{c}\text { Average } \\
\text { temperature } \\
\left({ }^{\circ} \mathrm{C}\right)^{*}\end{array}$ & $\begin{array}{c}\text { Annual rainfall } \\
\text { intensity }(\mathrm{mm})^{*}\end{array}$ \\
\hline R-S2 & Panji & Inpari 13 & Vegetative & 25.9 & 1,200 \\
R-S3 & Jangkar & Ciherang & Vegetative & 26.4 & 975 \\
R-S5 & Banyuputh & Local variety (a) & Vegetative & 22.8 & 2,092 \\
R-S6 & Kendit & Ciherang & Vegetative & 26.4 & 1,230 \\
R-J1 & Mayang & Cibogo & Vegetative & no data & no data \\
R-J2 & Silo & Sidenuk & Vegetative & -26.5 & 1,450 \\
R-J3 & Kalisat & Inpari 30 & Generative & -24.5 & 2,163 \\
R-S4 & Arjasa & Local variety (b) & Generative & -26.5 & 1,450 \\
R-S7 & Kapongan & Local variety (c) & Generative & 26.4 & 1,077 \\
R-J4 & Tempurejo & Cibogo & Generative & no data & no data \\
R-J5 & Ajung & Patiwi & Generative & 26 & 2,143 \\
R-J6 & Jenggawah & Aris & Generative & 26 & 1,952 \\
\hline
\end{tabular}

* Source: https://en.climate-data.org/

Table 2. Target resistance genes, primer sequences, annealing temperatures, and product sizes

\begin{tabular}{|c|c|c|c|c|}
\hline No. & Target genes & Primer sequences & $\begin{array}{c}\text { Annealing } \\
\text { temperature } \\
\left({ }^{\circ} \mathrm{C}\right) \\
\end{array}$ & $\begin{array}{l}\text { Product } \\
\text { (bp) }\end{array}$ \\
\hline 1 & Xal & $\begin{array}{l}\text { F: 5'-ACTGCCCTCTTGCACACGCCTTTGG-3' } \\
\text { R:5'-CCGGTACATCAGTATTGTCCATCGG-3' }\end{array}$ & 66 & 447 \\
\hline 2 & Xa3 & $\begin{array}{l}\mathrm{F}: 5^{\prime} \text { 'CCACAATGCCATGTCAGGTGGCATCCCTGCA-3' } \\
\text { R: 5'-AGGTGTTGGAGGATTGGCAT-3' }\end{array}$ & 67 & 255 \\
\hline 3 & $X a 4$ & $\begin{array}{l}\text { F: 5'-ATCGATCGATCTTCACGAGG3' } \\
\text { R : 5'-TGCTATAAAAGGCATTCGG-3' }\end{array}$ & 53 & 150 \\
\hline 4 & $X a 7$ & $\begin{array}{l}\text { F:5'-CGATCTTACTGGCTCTGCAACTCTGT-3' } \\
\text { R :5'-GCATGTCTGTGTCGATTCGTCCGTACGA-3' }\end{array}$ & 65 & $\begin{array}{l}1,170 \text { or } \\
294\end{array}$ \\
\hline 5 & Xa10 & $\begin{array}{l}\text { F: 5'-CAACGCCTATCTTCTGCATTTC-3' } \\
\text { R :5'-GTGACCCTAGTTTCTGGTTATG-3', }\end{array}$ & 53 & 604 \\
\hline 6 & $X a 5$ & $\begin{array}{l}\text { F:5'-AGCTCGCCATTCAAGTTCTTGAG-3' } \\
\text { R :5'-TGACTTGGTTCTCCAAGGCTT-3' }\end{array}$ & 57 & $\begin{array}{l}200,300 \\
\text { or } 400\end{array}$ \\
\hline 7 & Xa13 & $\begin{array}{l}\text { F:5'-GGCCATGGCTCAGTGTTTAT-3' } \\
\text { R :5'-GAGCTCCAGCTCTCCAAATG-3', }\end{array}$ & 55 & $\begin{array}{l}400 \text { or } \\
200\end{array}$ \\
\hline 8 & $X a 21$ & $\begin{array}{l}\text { F: 5'-CGATCGGTATAACAGCAAAAC-3' } \\
\text { R :5'-ATAGCAACTGATTGCTTGG-3' }\end{array}$ & 50 & 1400 \\
\hline
\end{tabular}


Detection of $X \boldsymbol{a}$ Genes. $X a$ gene sequences in rice were detected through polymerase chain reaction (PCR) using specific gene primers (Singh et al., 2015). Eight specific primers pairs were employed to amplify particular $X a$ sequences from the DNA template in the GoTaq ${ }^{\circledR}$ Green Master Mix (Promega, USA) at different annealing temperatures (Table 2). The PCR was performed in 35 cycles with initial denaturation at $94{ }^{\circ} \mathrm{C}$ for five minutes, denaturation at $94{ }^{\circ} \mathrm{C}$ for one minute, annealing for one minute, extension at $72{ }^{\circ} \mathrm{C}$ for one minute, and the final extension at $72{ }^{\circ} \mathrm{C}$ for 10 minutes (based on the Promega protocol). The PCR products were separated in agarose gel $(1.5 \% \mathrm{w} / \mathrm{v}$ in TAE buffer pH 8.0 (containing $40 \mathrm{mM}$ Tris, $20 \mathrm{mM}$ acetic acid, and $1 \mathrm{mM}$ EDTA) and visualized under UV light after staining with ethidium bromide $(10 \mathrm{mg} / \mathrm{L})$ for 10 minutes.

Statistical Analysis. The analysis of variance and Pearson correlation coefficient analysis were performed

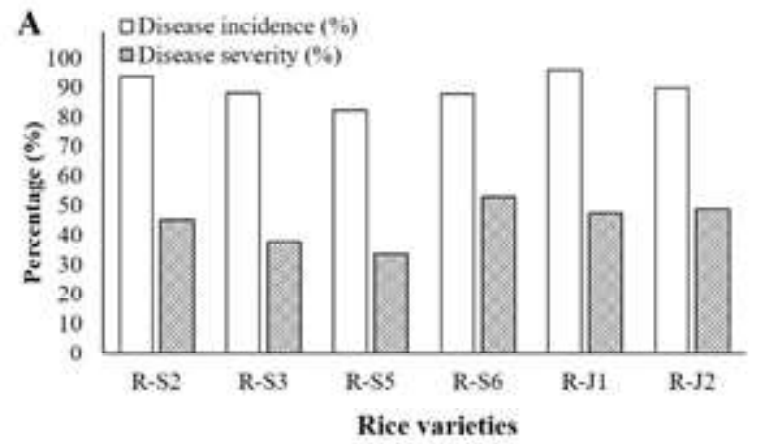

using Microsoft Excel 2016 for Windows to evaluate whether disease incidence and severity were related to plant growth stages, the presence of resistance genes, average temperature, and rainfall intensity. Results were considered significant at $p<0.05$.

\section{RESULTS AND DISCUSSION}

Disease Incidence and Severity. Disease incidence and severity observations were grouped based on the developmental stage of the plant-vegetative or generative. Overall, the mean values of disease incidence and severity in the vegetative stage (Figure 2A) were lower than those in the generative stage (Figure 2B). According to the data for disease incidence and severity, in relation to the resistance status of rice against BLB, the results showed that all varieties were in the same category of resistance, with a disease incidence of $>70 \%$ and disease severity of $25-50 \%$.

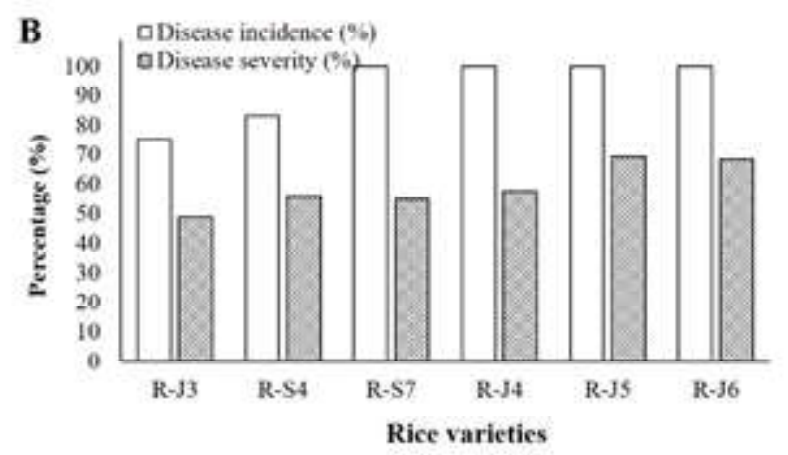

Figure 2. Disease incidence and severity data for all rice varieties at the vegetative (A) and generative (B) stages. The codes for the rice samples are the same as those listed in Table 1

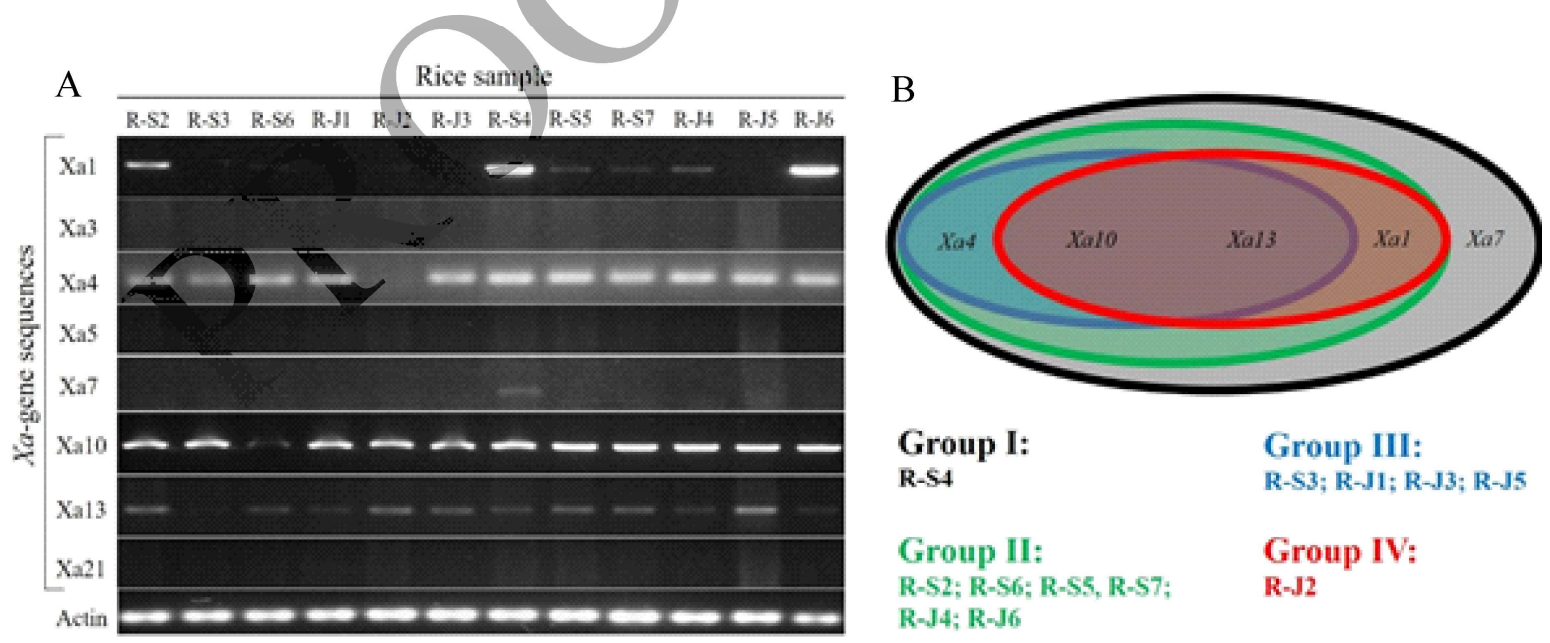

Figure 3. Rice sample codes represent the varieties given in Table 1. Xa gene sequences were amplified using primer pairs listed in Table 2. Actin was used as a control primer for all samples (A). All rice varieties are categorized into four groups according to the number of $X a$ gene sequences detected in the genome (B). Each group is represented by a different color according to the $\mathrm{Xa}$ gene composition (enclosed within the colored circles). 
Detection of $\mathrm{Xa}$ Resistance Genes in Rice. The PCR assay to detect the presence of particular $X a$ gene sequences showed that at least five $X a$ genes were present in most varieties, except for $\mathrm{Xa3}, \mathrm{Xa5}$, and $\mathrm{Xa2} 1$ (Figure 3A). Accordingly, the rice varieties were categorized into four groups. Group I included the rice varieties containing the most number of resistance genes (all five genes); only one local variety (R-S4) collected from Arjasa, Situbondo Regency was in this group. Group II consisted of all the rice varieties carrying the four $\mathrm{Xa}$ gene sequences, $\mathrm{Xa1}, \mathrm{Xa} 4, \mathrm{Xa10}$, and Xa14; most of the varieties (six varieties) belonged to this group. Group III and Group IV included rice varieties that had the same number of $X a$ gene sequences but in different combinations (Figure 3B).

Analysis of Factors Related to Disease Incidence and Severity. Results showed that disease incidence and severity were related to plant growth stage, the presence of resistance genes, and average temperature and rainfall intensity. Plant growth stage (vegetative or generative) had a significant effect on disease severity
$(F$-value $=11.266)$, but not on disease incidence $(F$ value $=0.517$; Table 3 )

In addition, there was a positive correlation between the presence of $X a$ genes and disease incidence or disease severity (Table 4). However, the Pearson correlation coefficients were small $(R=0.02$ for disease incidence and $R=0.15$ for disease severity), indicating that the relationship between the number of $X a$ genes and disease incidence or disease severity is weak.

The correlation between environmental factors (annual rainfall intensity and average temperature) and disease incidence or severity was also weak (Table 5). Only average temperature exhibited a strong correlation to disease incidence $(R=0.528 ; p<0.05)$; the correlation coefficient for this relationship was higher than that for the relationship with disease severity, indicating that the average temperature was more influential for disease incidence than for disease severity. In addition, the results strongly imply that disease severity is influenced by disease incidence since there was a strong positive correlation between the two $(R=$ $0.602, p<0.05$; Table 5).

Table 3. Analysis of variance between plant growth stages (vegetative or generative) against disease incidence and disease severity

\begin{tabular}{|c|c|c|c|c|}
\hline & & informa & & \\
\hline Source of variation & value & b-value & $F$-critical & Annotation \\
\hline Disease incidence & .517 & 0.489 & 4.965 & ns \\
\hline Disease severity & 1.266 & 0.007 & 4.965 & $*$ \\
\hline $\mathrm{ns}=$ not significant $;=$ sig & & & & \\
\hline $\begin{array}{c}\text { Table 4. Pearson's correlatic } \\
\text { disease severity }\end{array}$ & analys & the nun & of $X a$ genes & nst disease in \\
\hline & & cal infor & & \\
\hline Source of relatio & $R^{2}$ & $R$ & $P$-value & Annotation \\
\hline Disease incidence & 0.0003 & 0.02 & 0.96 & weak \\
\hline Disease severity & 0.0213 & 0.15 & 0.65 & weak \\
\hline
\end{tabular}

Table 5. Comparison of the Pearson's correlation coefficient between average temperature and annual rain intensity against disease incidence and disease severity

\begin{tabular}{|c|c|c|c|c|}
\hline & $\begin{array}{c}\text { Annual rainfall } \\
\text { intensity }\end{array}$ & $\begin{array}{c}\text { Average } \\
\text { temperature }\end{array}$ & Disease incidence & Disease severity \\
\hline Annual rainfall intensity & 1 & & & \\
\hline Average temperature & $-0.692^{b}$ & 1 & & \\
\hline Disease incidence & $-0.183^{a}$ & $0.528^{b}$ & 1 & \\
\hline Disease severity & $0.288^{\mathrm{a}}$ & $0.408^{\mathrm{a}}$ & $0.602^{b}$ & 1 \\
\hline
\end{tabular}

$\mathrm{a}=$ weak correlation; $\mathrm{b}=$ strong correlation. 
BLB, caused by $X$. oryzae pv. oryzae, depends on the interactions between the three disease triangle components (pathogen, host, and environmental conditions), especially when the interactions promote the development of the pathogen or disease (Agrios, 2005). The results of this study indicated that the growth stage of rice significantly influenced the severity, but not the incidence of BLB (Table 3). In addition, disease severity at the generative stage was higher than the vegetative stage, with the pathogen continuing to grow and the disease continuing to increase in severity from the vegetative stage (Figure $2 \mathrm{~A}$ ) to the generative stage (Figure 2B). This probably because rice is more susceptible to $X$. oryzae infection at the vegetative stage rather than at the generative stage, and by the time plants reach the generative stage, the disease has become more severe (Khaeruni et al., 2014). Furthermore, the impact of disease on yield is theoretically influenced by several factors, such as the resistance of the cultivar and environmental factors (Yoshimura et al., 1998).

Plant resistance is genetically dependent on resistant genes ( $R$ genes) that interact with pathogens, triggering resistance mechanisms (Vikal \& Bhatia, 2017). In rice, about $42 X a$ resistance genes have been identified and studied (Webb et al., 2010). However, this study showed that the presence of resistance genes only had a weak effect on disease incidence and severity in rice (Table 4). Nevertheless, the genetic analysis showed that all rice cultivars in Jember and Situbondo possess more than three $X a$ genes (Figure $3 \mathrm{~A}$ ); they were categorized accordingly into four groups depending on the $X a$ gene composition, with most rice cultivars carrying the Xa10 and Xa13 genes (Figure 3B).

Theoretically, each $X a$ gene has specific function and role in the defense mechanism against the BLB pathogen (Vikal \& Bhatia, 2017). In particular, the Xal gene detected in cultivar Groups I, II, and IV (Figure 3B) play a role in recognizing pathogens and increasing the efficiency of interaction with the $a v r$ gene (Yoshimura et al., 1998). In contrast to the Xal gene, the $\mathrm{Xa} 4$ gene detected in cultivars in Groups I, II, and III has a function in increasing the number of incompatible reactions between pathogens and hosts (Vikal \& Bhatia, 2017). Uniquely, the $X a 7$ gene present (together with Xa1, Xa4, Xa10, and Xa13; Figure 3A) only in the local variety R-S4 from Situbondo provides a mechanism for resistance through the biosynthesis of abscisic acid (Cohen et al., 2017). Although all cultivars carry $X a$ genes, all are susceptible to $X$. oryzae (Figure 2). Interestingly, rice varieties with $X a 10$ and $X a 13$ genes (known to encode, respectively, the executor of $\mathrm{R}$ protein in triggering a hypersensitive response and activating resistance, and transcription activator-like effectors), are more susceptible to BLB (Antony et al., 2010; Jeung et al., 2006; Wang et al., 2017). It is noteworthy that Xa10 and Xal3 are in all cultivars included in the susceptible resistance category in this study.

Environmental factors, such as wind, rain, irrigation, contact between plants, and others, may influence the spread of pathogens (Agrios, 2005). This study suggests that BLB incidence is influenced by the average temperature of both Regencies (Table 5). Optimally, the BLB pathogen grows at a temperature range between $25^{\circ} \mathrm{C}$ and $30^{\circ} \mathrm{C}$ (Niño-Liu et al., 2006). The average temperature observed in the rice fields of both Regencies, $22.8-26.5^{\circ} \mathrm{C}$, is well within the optimal range for the pathogen. Therefore, temperature may represent the most probable factor influencing BLB incidence and severity in Jember and Situbondo. This is supported by our finding that temperature has a strong impact on disease incidence. In addition, disease incidence and severity are strongly correlated due to the favorable conditions for the pathogen (Niño-Liu et al., 2006). In summary, the temperature in rice fields promotes infection of rice by $X$. oryzae, resulting in a higher incidence of disease, especially at the generative stage of rice; disease severity is simultaneously higher due to survival and establishment of the pathogen, which infects rice at the vegetative stage (Khaeruni et al., 2014).

Another factor influencing the development of BLB is the difference of pathogen types (pathotypes), with different pathogenic ability or virulence against host plants (Suparyono et al., 2004). Interestingly, X. oryzae strains are grouped into 12 pathotypes based on virulence against different rice varieties, and are widespread in Java and also found in lowland areas (Suryadi et al., 2016). Further identification of the pathotypes that infect rice cultivars in Jember and Situbondo is needed to obtain comprehensive information on the resistance status of all cultivars grown in these areas. This information will be useful for new rice cultivar development.

\section{CONCLUSION}

In conclusion, the results show that $X a 10$ and $X a 13$ genes are the most prevalent resistant genes, which are carried by all rice varieties in this study. One rice cultivar carries all five $\mathrm{Xa}$ genes $(\mathrm{Xa1}, \mathrm{Xa} 4, \mathrm{Xa}$, Xa10, 
and $\mathrm{Xa13}$ ). However, the presence of resistance genes, plant growth stage, and rainfall intensity have no strong correlation with disease incidence or severity. However, temperature has a strong influence on BLB disease incidence.

\section{ACKNOWLEDGMENTS}

The authors would like to thank the Ministry of Research, Technology, and Higher Education, the Republic of Indonesia (through the University of Jember) for funding this research through the Fundamental Research Grant Scheme (no. 061/SP2H/LT/DRPM/ 2019). Data collection was partially supported under the Hibah Pendukung IDB 2018 (contract no. 2944/ UN25.3.1/LT/2018).

\section{REFERENCES}

Agrios G. 2005. Plant Pathology. $5^{\text {th }}$ Edition. Elsevier Academic Press, Massachusetts.

Aktar MW, Sengupta D, \& Chowdhury A. 2009. Impact of pesticides use in agriculture: their benefits and hazards. Interdisc. Toxicol. 2(1): 1-12.

Almeida DM, Almadanim MC, Lourenço T, Abreu IA, Saibo NJS, \& Oliveira MM. 2016. Screening for abiotic stress tolerance in rice: salt, cold, and drought. In: Duque P (Ed.). Enviromental Responses in Plants. Methods in Molecular Biology. Vol. 1398. pp. 155-182. Humana Press. New York.

Antony G, Zhou J, Huang S, Li T, Liu B, White F, \& Yang B. 2010. Rice xal 3 recessive resistance to bacterial blight is defeated by induction of the disease susceptibility gene Os-11N3. The Plant Cell.22(11): 3864-3876.

Arunakumari K, Durgarani CV, Satturu V, Sarikonda KR, Chittoor PDR, Vutukuri B, Laha GS, Nelli APK, Gattu S, Jamal M, Prasadbabu A, Hajira S, \& Sundaram RM. 2016. Marker-assisted pyramiding of genes conferring resistance against bacterial blight and blast diseases into Indian rice variety MTU1010. Rice Sci. 23(6): 306-316.

Cohen SP, Liu H, Argueso CT, Pereira A, Vera Cruz C, Verdier V, \& Leach JE. 2017. RNA-Seq analysis reveals insight into enhanced rice $\mathrm{Xa} 7$-mediated bacterial blight resistance at high temperature. PLoS ONE. 12(11): e0187625.
Ilao S \& Lastimosa P. 1985. Research Techniques in Crops. PCARRD, National Science and Technology Authority. Laguna, Philippines.

Jeung JU, Heu SG, Shin MS, Vera Cruz C, \& Jena KK. 2006. Dynamics of Xanthomonas oryzae pv. oryzae populations in Korea and their relationship to known bacterial blight resistance genes. Phytopathology. 96(8): 867-875.

Khaeruni A, Taufik M, Wijayanto T, \& Johan EA. 2014. Perkembangan penyakit hawar daun bakteri pada tiga varietas padi sawah yang diinokulasi pada beberapa fase pertumbuhan. J. Fitopatol. Indones. 10(4): 119-125.

Mew T \& Misra J. 1994. A Manual of Rice Seed Health Testing. IRRI, Philippines.

Naqvi SAH. 2019. Bacterial leaf blight of rice: an overview of epidemiology and management with special reference to Indian sub-continent. Pak. J. Agri. Res. 32(2): 359-380.

Niño-Liu DO, Ronald PC, \& Bogdanove AJ. 2006. Xanthomonas oryzae pathovars: model pathogens of a model crop. Mol. Plant Pathol. $7(5): 303-324$.

Nisha S, Revathi K, Chandrasekaran R, Kirubakaran SA, Sathish-Narayanan S, Stout MJ, \& SenthilNathan S. 2012. Effect of plant compounds on induced activities of defense-related enzymes and pathogenesis related protein in bacterial blight disease susceptible rice plant. Physiol. Mol. Plant Pathol. 80: 1-9.

Perumalsamy S, Bharani M, Sudha M, Nagarajan P, Arul L, Saraswathi R, Balasubramanian P, \& Ramalingam J. 2010. Functional marker-assisted selection for bacterial leaf blight resistance genes in rice (Oryza sativa L.). Plant Breed. 129(4): 400-406.

Sambrook J \& Russell DW. 2001. Molecular Cloning: A Laboratory Manual. 3rd Edition. Cold Spring Harbor Laboratory Press, New York.

Singh AK, Dharmraj E, Nayak R, Singh PK, \& Singh NK. 2015. Identification of bacterial leaf blight resistance genes in wild rice of eastern India. Turk. J. Bot. 39(6): 1060-1066.

Suparyono, Sudir, \& Suprihanto. 2004. Pathotype profile of Xanthomonas oryzae pv. oryzae isolates from the rice ecosystem in Java. Indones. J. Agric. Sci. 5(2): 63-69. 
Suryadi Y, Samudra IM, Priyatno TP, Susilowati DN, Lestari P, Fatimah, \& Kadir TS. 2016. Determination of pathotypes from Indonesian Xanthomonas oryzae pv. oryzae population causing bacterial leaf blight and their reactions on differential rice. Makara J. Sci. 20(3): 109118.

Susanto U \& Sudir. 2012. Ketahanan genotipe padi terhadap Xanthomonas oryzae pv. oryzae patotipe III, IV, VIII. Penelitian Pertanian Tanaman Pangan. 31(2): 108-116.

Vikal Y \& Bhatia D. 2017. Genetics and Genomics of Bacterial Blight Resistance in Rice. Advance in International Rice Research, Jinquan Li. IntechOpen. <https://www.intechopen.com/ books/advances-in-international-rice-research/ genetics-andgenomics-of-bacterial-blightresistance-in-rice>.

Wahyudi AT, Meliah S, \& Nawangsih AA. 2011. Xanthomonas oryzae pv. oryzae bakteri penyebab hawar daun pada padi: isolasi, karakterisasi, dan telaah mutagenesis dengan transposon. Makara J. Sci. 15(1): 89-96.
Wang J, Tian D, Gu K, Yang X, Wang L, Zeng X, \& Yin Z. 2017. Induction of Xa10-like genes in rice cultivar nipponbare confers disease resistance to rice bacterial blight. Mol. Plant-Microbe Interact. 30(6): 466-477.

Webb KM, Garcia E, Cruz CMV, \& Leach JE. 2010. Influence of rice development on the function of bacterial blight resistance genes. Eur. J. Plant Pathol. 128(3): 399-407.

Yoshimura S, Yamanouchi U, Katayose Y, Toki S, Wang ZX, Kono I, Kurata N, Yano M, Iwata N, \& Sasaki T. 1998. Expression of Xal, a bacterial blightresistance gene in rice, is induced by bacterial inoculation. PNAS. 95(4): 1663-1668. 